\title{
Calibrating and Validating a FE Model for Long-term Behavior of RC Beams
}

\author{
NIKOLA D. TOŠIĆ, University of Belgrade, \\ Faculty of Civil Engineering, Belgrade \\ SNEŽANA B. MARINKOVIĆ, University of Belgrade, \\ Faculty of Civil Engineering, Belgrade
}

\author{
Original scientific paper \\ UDC: 624.012 .45 .042
}

This study presents the research carried out in finding an optimal finite element (FE) model for calculating the long-term behavior of reinforced concrete $(R C)$ beams. A multi-purpose finite element software DIANA was used. A benchmark test in the form of a simply supported beam loaded in fourpoint bending was selected for model calibration. The result was the choice of 3-node beam elements, a multi-directional fixed crack model with constant stress cut-off, nonlinear tension softening and constant shear retention and a creep and shrinkage model according to CEB-FIP Model Code 1990. The model was then validated on 14 simply supported beams and 6 continuous beams. Good agreement was found with experimental results (within $\pm 15 \%$ ).

Key words: creep, shrinkage, reinforced concrete, beams, FE

\section{INTRODUCTION}

Non-linear computer analysis methods have seen remarkable advancement in the last half-century with a lot of research activity in the field of constitutive modeling of reinforced concrete behavior and in the development of sophisticated analysis algorithms [1].

The state-of-the-art in non-linear finite element analysis of reinforced concrete has progressed to the point where such procedures are close to being practical, every-day tools for design office engineers.

At the same time the long-term behavior of concrete i.e. creep and shrinkage, remains one of the most hotly debated areas in the field of constitutive modeling of concrete. There is no uniform view on this phenomenon and a vast variety of models exist for describing the rheological properties of concrete.

The aim of the present study is to find a relatively simple and robust material and numerical model that can be understandable to the practicing engineer. For this purpose a benchmark test was selected and a FE model calibrated. The model was then validated on other experiments with good agreement while drawing significant conclusions.

Author's address: Nikola Tošić, University of Belgrade, Faculty of Civil Engineering, Belgrade, Bulevar kralja Aleksandra 73

Paper received: 24.03.2014.

Paper accepted: 25.04.2014.

\section{FE MODEL SELECTION AND CALIBRATION}

\subsection{TNO DIANA}

DIANA is a general purpose finite element code, based on the Displacement Method (DIANA=DIsplacement ANAlyser) [2]. It has been under development at TNO DIANA BV since 1972. Since then it was proven and tested to be an extensive multi-purpose finite element software package dedicated, but not exclusive to a wide range of problems arising in civil engineering including structural, geotechnical, tunneling, earthquake disciplines and oil and gas engineering. The program includes extensive material models, element libraries and analysis procedures, which are based on the latest and the most advanced finite element analysis techniques. DIANA has been equipped with powerful solvers in order to optimize the solution procedures for all types of linear and nonlinear complex models with accurate results and fast computations. Its more than abundant offer of concrete material models and model code libraries, finite elements and nonlinear static and transient analysis procedures was the reason for choosing it in this study.

\subsection{Experiment used as creep and shrinkage benchmark test}

DIANA User's Manual Concrete and Masonry Analysis (ConcMas) [3] elaborates numerous examples of analysis of concrete and masonry structures. Part IV Chapter 13 presents an example of long-term behavior of a reinforced concrete beam. The example 
actually models the experiment carried out by Jaccoud and Favre from 1979 through 1982. [4]. In this well-known experiment various reinforced simply supported concrete one-way slabs were loaded with different load intensities and their long-term behavior was monitored. The quality of this research is it's scope and thoroughness. One-way slabs were executed well in terms of achieved material properties, reinforcement ratio and span-to-depth ratio. All relevant material properties (compressive and tensile strength, modulus of elasticity) were measured.

The most numerous experimental series - series $\mathrm{C}$, consisted of 11 slabs with the same reinforcement ratio loaded in four-point bending with different loads, ranging from 0.2 to 0.6 of the slabs' ultimate load (UL). There were slabs that remained uncracked as well as those which cracked under the loading. The slabs were loaded at the age of 28 days, sufficiently quickly and most importantly, the initial deflection was measured quickly ( 5 minutes after loading). Deflection was measured for one year. Because of these qualities in 1993 the RILEM committee TC 114 adopted the $\mathrm{C}$-series as benchmark tests for computer software for creep and shrinkage [5], [6]. Table 1 lists the most important data for slab C15.

ConcMas [3] presents the numerical analysis for slabs C11 and C15 (slab C11 is loaded with 0.2.UL and slab $\mathrm{C} 15$ with $0.6 \cdot \mathrm{UL})$. In this manual a material and FE model and analysis procedure, deemed most fit by DIANA developers were selected and results Table 1. Experimental data from [4]

\begin{tabular}{|c|c|c|c|c|c|c|c|c|}
\hline Experiment & Type & $\begin{array}{l}\text { Span } \\
(\mathrm{mm})\end{array}$ & $\begin{array}{l}\text { Width } \\
(\mathrm{mm})\end{array}$ & $\begin{array}{l}\text { Height } \\
(\mathrm{mm})\end{array}$ & $\begin{array}{l}\mathrm{A}_{\mathrm{a} 1}^{\mathrm{b}} \\
\left(\mathrm{mm}^{2}\right)\end{array}$ & $\begin{array}{l}\mathrm{A}_{\mathrm{a} 2}{ }^{\mathrm{c}} \\
\left(\mathrm{mm}^{2}\right)\end{array}$ & $\begin{array}{l}\mathrm{RH} \\
(\%)\end{array}$ & $\begin{array}{l}\mathrm{f}_{\mathrm{cm}, 28}{ }^{\mathrm{d}} \\
(\mathrm{MPa})\end{array}$ \\
\hline $\mathrm{J} \& \mathrm{~F} \mathrm{C} 15$ & $4 \mathrm{~PB}^{\mathrm{a}}$ & 3100 & 750 & 160 & 565 & 57 & 60 & 29.29 \\
\hline \multicolumn{9}{|c|}{ 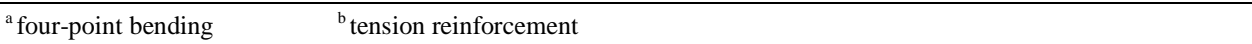 } \\
\hline \multicolumn{9}{|c|}{${ }^{\mathrm{c}}$ compression reinforcement ${ }^{\mathrm{d}}$ compress } \\
\hline $\mathrm{f}_{\mathrm{ct}, 28}{ }^{\mathrm{e}}(\mathrm{MPa})$ & $\begin{array}{l}\mathrm{E}_{\mathrm{cm}, 28}^{\mathrm{f}} \\
(\mathrm{GPa})\end{array}$ & $\begin{array}{l}\mathrm{t}_{\text {loading }} \\
\text { (days) }\end{array}$ & $\begin{array}{l}\mathrm{t}_{\text {final }} \\
\text { (days) }\end{array}$ & $\begin{array}{l}\mathrm{M}_{\mathrm{cr}}^{\mathrm{g}} \\
(\mathrm{kNm})\end{array}$ & $\begin{array}{l}\mathrm{M}_{\mathrm{sw}}^{\mathrm{h}} \\
(\mathrm{kNm})\end{array}$ & $\begin{array}{l}\mathrm{M}_{\mathrm{F}}^{\mathrm{i}} \\
(\mathrm{kNm})\end{array}$ & $\begin{array}{l}\mathrm{w}(\mathrm{i}) \\
(\mathrm{mm})\end{array}$ & $\mathrm{w}(\mathrm{t})(\mathrm{mm})$ \\
\hline 2.90 & 28.70 & 28 & 393 & 9.280 & 3.54 & 15.725 & 10.0 & 19.50 \\
\hline \multicolumn{9}{|c|}{${ }^{\mathrm{e}}$ tensile strength after 28 days ${ }^{\mathrm{f}}$ elasticity modulus after 28 days } \\
\hline \multicolumn{9}{|l|}{${ }^{\mathrm{g}}$ cracking moment } \\
\hline
\end{tabular}

For cracking, a Multi-Directional Fixed Crack model was used. Besides this model, DIANA also offers a Total Strain Crack model. The advantages of the chosen model in similar applications is thoroughly elaborated in literature [7], [8], [9]. This model requires the definition of stress cut-off, tension softening and shear retention.

For the initial model constant stress cut-off, nonlinear tension-softening according to Moelands and Reinhardt [10] and constant shear retention were chosen. The additional input parameters are the tensile stre- presented. However, in this paper only the slab C15 was analyzed since it was cracked and is a more realistic representation of real-life structures.

\subsection{Initial FE model description}

In the adopted initial FE model only one half of the slab was modeled, because of symmetry. This half was modeled with seven three-node CL9BE beam elements, $200 \mathrm{~mm}$ length each [3]. CL9BE is a numerically integrated two-dimensional element in which shear deformation is included according to the Mindlin-Reissner theory.

In the axial direction, a default 2-point Gauss integration is used and in the thickness direction a 9point Simpsonian integration. Due to the twodimensional idealization, all reinforcements at one side were modeled by one embedded bar.

Two load sets were modeled - load set 1 was a nodal force of $15.725 \mathrm{kN}$ applied at the third of the span and load set 2 was dead weight loading.

The necessary material properties were standard elastic properties, creep, shrinkage and cracking properties.

The elastic properties are the concrete modulus of elasticity, Poisson's ratio and the reinforcement steel modulus of elasticity. A divergence was made here from the example in ConcMas [3]. The material properties used in the User's Manual were average properties for slabs $\mathrm{C} 11$ and $\mathrm{C} 15$ whereas in this study the exact properties for slab C15 were used, Table 1 . ngth $f_{t}$, fracture energy $G_{f}$, crack bandwidth $h_{c r}$ and shear retention factor $\beta$. The fracture energy is considered a material property and was calculated according to the CEB-FIP Model Code 1990 [11]. The crack bandwidth is dependent on the element size (equals the length of the beam elements; in reality can be estimated from stirrup spacing). These three parameters - $f_{t}, G_{f}$ and $h_{c r}$ determine the release of Mode-I fracture energy if the tensile strength is violated. It is possible that the elements of the discretization are so large that the equivalent length of an element results 
in a snap-back in the constitutive model and the concept of objective fracture energy which has been assumed is no longer satisfied. A snap-back in the constitutive model is possible if the absolute value of the initial slope of the softening diagram is greater than the Young's modulus of the material, if it is assumed that the initial tangent of the tension softening diagram results in the greatest value of the tangent stiffness. This criterion is always violated in the case of tension softening according to Moelands and Reinhardt [12]. The shear retention factor was in this example chosen rather arbitrarily and there is no discussion on this choice. A measure of aggregate interlock, shear retention across a crack is best described by a descending linear function of the crack strain. Since DIANA doesn't offer such an option, a constant value of 0.2 chosen in this example is accepted as appropriate.

Creep is modeled by rheological Maxwell chains, consisting of several spring and dashpot chains [3]. DIANA offers the option of deriving the chain properties from standard creep models like the CEB-FIP Model Code 1990 [11]. The example in ConcMas [3] uses a built-in CEB-FIP Model Code creep model which requires only parameters such as the loading age $t_{0}$, modulus of elasticity $E_{t 0}$, mean compressive strength $f_{c m}$, notational size $h_{0}(=2 \cdot A / O)$, cement type, relative humidity $R H$ and ambient temperature $T_{e n v}$. From these parameters the creep function $J\left(t, t_{0}\right)$ is calculated. This model is only valid within the range of linear creep i.e. when $\sigma_{c} \leq 0.4 f_{c k}$.

Shrinkage is modeled as age-dependent initial strain. The built-in CEB-FIP model was used [11]. The required parameters are the same as for the creep model. Shrinkage strain starts at the end of the curing period, in this case 7 days.

The input parameters are shown in Table 2.

Table 2. Input parameters for the initial FE model

\begin{tabular}{llll}
\hline Reinforcement modulus & $E_{a}$ & 210 & $\mathrm{kN} / \mathrm{mm}^{2}$ \\
Concrete modulus & $E_{c}$ & 28.7 & $\mathrm{kN} / \mathrm{mm}^{2}$ \\
Tensile strength & $f_{t}$ & 2.9 & $\mathrm{~N} / \mathrm{mm}^{2}$ \\
Loading age & $t_{0}$ & 28 & days \\
Relative humidity & $R H$ & 60 & $\%$ \\
Ambient temperature & $T_{e n v}$ & 20 & ${ }^{\circ} \mathrm{C}$ \\
\hline Notational member size & $h_{0}$ & 132 & $\mathrm{~mm}$ \\
Crack bandwidth & $h_{c r}$ & 200 & $\mathrm{~mm}$ \\
Fracture energy & $G_{f}$ & 0.064 & $\mathrm{~N} \cdot \mathrm{mm} / \mathrm{mm}^{2}$ \\
Shear retention factor & $\beta$ & 0.2 & - \\
\hline
\end{tabular}

For the analysis procedure the following was adopted: first the dead weight load is applied, then the point load and finally a transient analysis is carried out, calculating the creep and shrinkage effects for a period of 365 days. Since there is no cracking under the dead weight load it was applied in one step with no step size control. For the point load automatic load step control is used. This is done using an Iteration Based Adaptive Loading method combined with a Spherical Path Arc-length method to control for snapback behavior [13]. Several parameters such as maximum, minimum and initial step size, number of load steps, number of maximum iterations and convergence criteria are defined. Creep and shrinkage is analyzed using time steps in days. The time stepping scheme is composed by incrementing the time steps logarithmically [3]. The selected output data are internal forces and moments, global displacements, concrete and reinforcement stresses and crack strains. Results are presented in Table 3.

Table 3. Results of FE analysis compared to measured values

\begin{tabular}{lllll}
\hline \multirow{2}{*}{ Exp. } & $\begin{array}{l}\text { Time } \\
\text { (days) }\end{array}$ & \multicolumn{2}{l}{ Deflection $(\mathrm{mm})$} & FE/Exp. \\
\cline { 3 - 4 } & FE & Experiment & $(\%)$ \\
\hline J\&F & 0 & 13.2 & 10.0 & 132 \\
C15 & 365 & 21.4 & 19.5 & 109.7 \\
\hline
\end{tabular}

As can be seen the calculated deflections at slabs' midspan fit fairly good with the measured values. There is a larger discrepancy in the initial deflection, which can only partially be explained by uncertainties tied to the tensile strength and fracture energy. Still the results are within $30 \%$ which can be considered a limit for "satisfactory" models [14]. The results are more accurate for the long-term deflection which follows the experimental curve rather well and ends within $10 \%$ of the measured value, enough to deem the model "good" [14]. However, the fact that the difference is reduced from $30 \%$ to $10 \%$ during the time analysis can indicate that the creep and shrinkage models underestimate deflection.

\subsection{Model calibration}

The next step in this study involved finding whether it was possible to find a more accurate model for this experiment. The varied model parameters were:

- Finite element type

- Tension softening relation

- Creep and shrinkage model

For finite element types, two different beam elements were used - CL12B and CL15B with 4 and 5 nodes, respectively. Element length was kept constant at $200 \mathrm{~mm}$. In the axial direction a default 3-point and 4-point Gauss integration is used respectively while in the thickness direction a 9-point Simpsonian integration is kept same as before. The use of plane stress and solid elements was also investigated. A quadrilateral, 8 node plane stress element, CQ16M was used with a default $2 \times 2$ Gauss integration scheme. 
Element dimensions were $50 \times 40 \mathrm{~mm}$. A brick, 8 node solid element, HX24L was also used with a default $2 \times 2 \times 2$ Gauss integration scheme. Element dimensions were $75 \times 80 \times 75 \mathrm{~mm}$.

For tension softening relations, DIANA offers 5 models - brittle, linear, multilinear, nonlinear according to Moelands and Reinhardt [10] and nonlinear according to Hordijk et al. [15]. Multilinear tension softening was not considered as it is simply a crude transition between linear and nonlinear relations. In linear and nonlinear (Hordijk et al.) tension softening it was checked whether the absolute value of the initial slope of the softening diagram is greater than the Young's modulus of the material.

This criterion can be written as:

$$
\varepsilon_{n n, u l t}^{c r} \geq-\frac{f_{t}}{E} \frac{d y}{d x} \mid x=0
$$

where $\varepsilon_{n}^{c}$ is the ultimate crack strain.

For the selected input parameters it was found that the criterion was violated in the case of nonlinear tension softening according to Hordijk et al. The recommended action in that case is the reduction of the tensile strength [12] in accordance with:

$$
f_{t}=\left(0.739 \frac{G_{f}^{l}}{h}\right)^{\frac{1}{2}}
$$

The choice of reducing the tensile strength has physical meaning since the variations in tensile strength can be relatively large and can increase with increasing sampling size (i.e. in larger finite elements). In this way the tensile strength was reduced from 2.90 $\mathrm{MPa}$ to $2.61 \mathrm{MPa}$.

For modeling creep and shrinkage by using model codes, besides the CEB-FIP Model Code 1990, DIANA offers the possibility of using the American ACI 209R-92 model code [16] and the Dutch NEN 6720 model code [17]. DIANA's built-in module was used, where the user only needs to specify the required input parameters without further calculation.

The analysis procedure was kept constant. In total this gave 9 parametric variations. The results are presented in Table 4. The results show that all the parameter variations offer little improvement. It has to be noted that since only one parameter was varied in each model there is no information on possible parameter interactions and possible synergetic effects. However it was found that, within this kind of parametric study, a choice of nonlinear tension softening according to Hordijk et al. together with CL9BE beam elements, constant stress cut-off, constant shear retention and creep and shrinkage according to CEBFIP Model Code 1990 is the most accurate model.

Table 4. Results of the FE parametric study

\begin{tabular}{lllll}
\hline $\begin{array}{l}\text { Varied } \\
\text { parameter }\end{array}$ & $\begin{array}{l}\mathrm{w}(\mathrm{i}) \\
(\mathrm{mm})\end{array}$ & $\begin{array}{l}\text { FE/Exp. } \\
(\%)\end{array}$ & $\begin{array}{l}\mathrm{w}(\mathrm{t}) \\
(\mathrm{mm})\end{array}$ & $\begin{array}{l}\text { FE/Ex } \\
\mathrm{p} .(\%)\end{array}$ \\
\hline Initial model & 13.2 & 132 & 21.4 & 109.7 \\
CL12B element & 13.2 & 132 & 21.5 & 110.3 \\
CL15B element & 13.2 & 132 & 21.4 & 109.7 \\
CQ16M element & 13.0 & 130 & 22 & 112.8 \\
HX24L element & 13.9 & 139 & 22.4 & 114.9 \\
Brittle cracking & 13.3 & 133 & 21.4 & 109.8 \\
Linear tension & 13.3 & 133 & 21.4 & 109.8 \\
soft. & & & & \\
Nonlinear tens. & & & & \\
soft. Hordijk et & 13.0 & 130 & 20.1 & 103.1 \\
al. & & & & \\
ACI 209R-92 & 13.2 & 132 & 17.6 & 90.3 \\
NEN 6720 & 13.2 & 132 & 21.3 & 109.2 \\
\hline
\end{tabular}

\section{FE MODEL VALIDATION}

\subsection{Model validation on simply supported beams}

In various literature guidance can be found on the subject of FE model validation [1]. In this process the most important step is the validation of the proposed model on a set of carefully chosen experiments of the same type. In this case that includes simply supported beams loaded in four-point bending or by a uniformly distributed load (UDL). The number of such experiments properly and carefully executed isn't large -in 1988. Espion found only 29 research programs of sufficient quality [18]. In this work 13 different models from 3 research programs were validated. The chosen experiments were Washa and Fluck, 1952 [19], Glanville and Thomas, 1939 [20] and Portland Cement Association, 1950 [21].

The research performed by Washa and Fluck [19] is practically the first systematical and methodical research of long-term behavior of RC beams [14]. Beams of different cross sections and different amounts of compressive reinforcement were loaded by a uniformly distributed load after 14 days and deflections were measured for $2^{1 / 2}$ years (913days). Among the necessary parameters, relative humidity was not controlled but in [18] a value of $50 \%$ is recommended. The tensile strength of concrete is not reported. The 14-day tensile strength was calculated according to CEB-FIP Model Code 1990. In the analysis procedure, step size control was used for dead weight load as it is practically identical to the cracking load as well as for the uniformly distributed additional load.

Glanville and Thomas [20] carried out the first research of long-term behavior of RC beams under co- 
ntrolled environmental conditions $(R H=65 \%)$. Two rather heavily reinforced beams are considered here, loaded at 24 and 25 days in four-point bending for 200 days. Unfortunately data had to be taken from [18] as the original was not available to the authors. The values of the modulus of elasticity and concrete tensile strength aren't presented and had to be calculated according to CEB-FIP Model Code 1990.

The analysis procedure is identical to the one in section 2.3 i.e. dead weight load is applied in one step while step size control is used for the point load. The results of the research by the Portland Cement Association [21] performed in the laboratories in Skokie, Illinois were never published but are me-

Table 5. Experimental data from [19], [20] and [21]

\begin{tabular}{lllllllll}
\hline Experiment & $\mathrm{L}(\mathrm{mm})$ & $\mathrm{b}(\mathrm{mm})$ & $\mathrm{d}(\mathrm{mm})$ & $\begin{array}{l}\mathrm{A}_{\mathrm{a} 1} \\
\left(\mathrm{~mm}^{2}\right)\end{array}$ & $\begin{array}{l}\mathrm{Aa}_{2} \\
\left(\mathrm{~mm}^{2}\right)\end{array}$ & $\begin{array}{l}\mathrm{f}_{\mathrm{cm}, 28} \\
(\mathrm{MPa})\end{array}$ & $\begin{array}{l}\mathrm{w}(\mathrm{i}) \\
(\mathrm{mm})\end{array}$ & $\begin{array}{l}\mathrm{w}(\mathrm{t}) \\
(\mathrm{mm})\end{array}$ \\
\hline W\&F A1/A4 & 6096 & 203.2 & 304.8 & 852 & 852 & 28.1 & 13.46 & 23.62 \\
W\&F A2/A5 & 6096 & 203.2 & 304.8 & 852 & 400 & 28.1 & 15.75 & 32.26 \\
W\&F A3/A6 & 6096 & 203.2 & 304.8 & 852 & 0 & 28.1 & 17.02 & 44.70 \\
W\&F B1/B4 & 6096 & 152.4 & 203.2 & 400 & 400 & 23.58 & 23.37 & 51.05 \\
W\&F B2/B5 & 6096 & 152.4 & 203.2 & 400 & 200 & 23.58 & 24.89 & 65.02 \\
W\&F B3/B6 & 6096 & 152.4 & 203.2 & 400 & 0 & 23.58 & 26.42 & 86.36 \\
W\&F D1/D4 & 3810 & 304.8 & 127 & 516 & 516 & 25.11 & 11.94 & 27.69 \\
W\&F D2/D5 & 3810 & 304.8 & 127 & 516 & 258 & 25.11 & 14.22 & 33.78 \\
W\&F D3/D6 & 3810 & 304.8 & 127 & 516 & 0 & 25.11 & 17.78 & 48.51 \\
G\&T X49 & 1830 & 101.6 & 209.6 & 400 & 0 & 24.0 & 1.42 & 3.48 \\
G\&T 88D & 1830 & 101.6 & 209.6 & 400 & 0 & 28.1 & 1.57 & 3.63 \\
PCA 40NA & 3048 & 152 & 305 & 849 & 0 & 26.9 & 4.25 & 10 \\
PCA 60NA & 3048 & 152 & 305 & 1019 & 0 & 37.4 & 4.9 & 9.9 \\
\hline
\end{tabular}

Table 6. FE model data for [19], [20] and [21]

\begin{tabular}{cccccc}
\hline Exp. & Elem. length & $E_{c}\left(\mathrm{kN} / \mathrm{mm}^{2}\right)$ & $f_{t}\left(\mathrm{~N} / \mathrm{mm}^{2}\right)$ & $R H(\%)$ & $G_{f}\left(N \cdot m m / m m^{2}\right)$ \\
\hline W\&F A-ser. & 381 & 20.37 & 2.01 & 50 & 0.058 \\
W\&F B-ser. & 254 & 18.75 & 1.70 & 50 & 0.051 \\
W\&F D-ser. & 210 & 18.40 & 1.80 & 50 & 0.053 \\
G\&T X49 & 230 & 28.62 & 1.88 & 65 & 0.061 \\
G\&T 88D & 230 & 30.21 & 2.20 & 65 & 0.06 \\
PCA 40NA & 250 & 29.90 & 2.14 & 50 & 50 \\
PCA 60NA & 250 & 33.37 & 2.87 & 50 & 0.076 \\
\hline
\end{tabular}

ntioned by various researchers [18]. Two beams with different reinforcement ratios are considered.

The beams are loaded at 28 days by different loads and deflections are monitored over a period of 270 days. The values of the modulus of elasticity and concrete tensile strength aren't presented and had to be calculated according to CEB-FIP Model Code 1990. The analysis procedure is identical to the one in section 2.3 i.e. dead weight load is applied in one step while step size control is used for the point load.

The experimental data is presented it Table 5 and the FE model data in Table 6 . The results of the numerical analyses can be seen in Table 7 . 
Table 7. Results of FE analyses vs. measured values, [19], [20] and [21]

\begin{tabular}{llllr}
\hline Exp. & $\begin{array}{l}\text { w(i) } \\
(\mathrm{mm})\end{array}$ & $\begin{array}{l}\text { FE/Exp. } \\
(\%)\end{array}$ & $\begin{array}{l}\mathrm{w}(\mathrm{t}) \\
(\mathrm{mm})\end{array}$ & $\begin{array}{r}\text { FE/Ex } \\
\text { p. }(\%)\end{array}$ \\
\hline W\&F A1/A4 & 15.5 & 115.2 & 24.3 & 102.9 \\
W\&F A2/A5 & 16.4 & 104.1 & 30.5 & 94.5 \\
W\&F A3/A6 & 17.3 & 101.7 & 43.7 & 97.8 \\
W\&F B1/B4 & 27.1 & 116.0 & 48.8 & 95.6 \\
W\&F B2/B5 & 27.7 & 111.3 & 58.1 & 89.4 \\
W\&F B3/B6 & 28.5 & 107.9 & 80.4 & 93.1 \\
W\&F D1/D4 & 15.8 & 132.3 & 26.9 & 97.1 \\
W\&F D2/D5 & 16.4 & 115.3 & 32.8 & 97.1 \\
W\&F D3/D6 & 17.1 & 96.2 & 47.9 & 98.7 \\
G\&T X49 & 1.66 & 116.9 & 3.65 & 104.9 \\
G\&T 88D & 1.63 & 103.8 & 3.42 & 94.2 \\
PCA 40NA & 4.09 & 96.2 & 8.63 & 86.3 \\
PCA 60NA & 4.74 & 96.7 & 8.94 & 90.3 \\
\hline & $\mu=$ & 108.7 & $\mu=$ & 95.5 \\
& $\sigma=$ & 10.5 & $\sigma=$ & 5.2 \\
\hline
\end{tabular}

Very good agreement with measured values is achieved with all results, except one, falling within $\pm 15 \%$ of the experimental values. There is one drawback that significantly diminishes the quality of any FE analysis prediction. In Washa and Fluck's study no tensile strength is reported while in the other two studies neither the tensile strength nor the elasticity modulus are given. Having in mind this drawback, some trends can be outlined. As in the benchmark test, accuracy is lower in the case of initial deflection. This can in part be explained by the unreported material properties and in the other part by the inadequacy of the FE model itself. In case of the initial deflection there is a clear trend of increasing accuracy with decreasing compressive reinforcement.

It would seem that the adopted Multi-Directional Fixed Crack model is intrinsically less stiff than reallife structures and the presence of compressive reinforcement only further softens it i.e. there is a reduction of concrete stiffness due to compressive reinforcement presence, but it isn't adequately accounted for in the overall stiffness. As for the longterm deflection, accuracy seems to be better. However taking into account the overestimation of initial deflection, it seems that the CEB-FIP creep and shrinkage model underestimates the long-term deflection development (although in Washa and Fluck's study relative humidity wasn't controlled; the adopted value of $50 \%$ is assumed to be an average).

\subsection{Model validation on continuous beams}

In [1], among the guidelines given for proper FE model validation, it is stated that a model should be tested in several different applications, not only in the application for which it was calibrated. In this study a choice was made to further validate the model on continuous beams. There exists a small number of good research programs in this area [18]. Continuous beams are also significant because of a new factor that influences their long-term behavior - moment redistribution due to cracking. The aim of the final step in this study was to test whether the proposed model captures these influences.

One research was selected for this phase an experiment carried out by Washa and Fluck in 1956 [22] after the one in 1952 [19]. Together these two experiments were conceived in such a way that they can be interpreted together. The two-span beams were of the same cross-sections and spans and long-term behavior was monitored for $2^{1 / 2}$ years (910 days). In this study series $\mathrm{X}$ and $\mathrm{Y}$ were selected which correspond to series $\mathrm{B}$ and $\mathrm{D}$ in [19].

Compressive reinforcement was again varied from being equal to the tension reinforcement, half of the tension reinforcement and zero. The load applied at the age of 28 days was selected in such a way that the maximum bending moment in the span is equal to the corresponding moment of the simply supported beams in [19]. Again the tensile strength of concrete isn't reported and had to be calculated according to CEB-FIP. The FE model data is presented in Table 8 and the experimental data in Table 9. Numerical analysis results are presented in Table 10.

Table 8. FE model data for experiment [22]

\begin{tabular}{llllll}
\hline Exp. & $\begin{array}{l}\text { El. } \\
\text { length } \\
(\mathrm{mm})\end{array}$ & $\begin{array}{l}E_{c, 28} \\
\left(\mathrm{kN} / \mathrm{mm}^{2}\right)\end{array}$ & $\begin{array}{l}f_{t, 28} \\
\left(\mathrm{~N} / \mathrm{mm}^{2}\right)\end{array}$ & $\begin{array}{l}R H \\
(\%)\end{array}$ & $\begin{array}{l}G_{f} \\
N \cdot m m / m^{2}\end{array}$ \\
\hline X-ser. & 254 & 23.24 & 2.02 & 0 & 0.058 \\
Y-ser. & 210 & 23.27 & 2.19 & 0 & 0.061 \\
\hline
\end{tabular}

Table 9. Experimental data from [22]

\begin{tabular}{lllllllllll}
\hline Exp. & $\mathrm{L}(\mathrm{mm})$ & $\mathrm{b}(\mathrm{mm})$ & $\mathrm{d}(\mathrm{mm})$ & $\begin{array}{l}\text { Span } \\
\mathrm{A}_{\mathrm{a} 1}\left(\mathrm{~mm}^{2}\right)\end{array}$ & $\mathrm{A}_{\mathrm{a} 2}\left(\mathrm{~mm}^{2}\right)$ & $\mathrm{A}_{\mathrm{a} 1}\left(\mathrm{~mm}^{2}\right)$ & $\mathrm{A}_{\mathrm{a} 2}\left(\mathrm{~mm}^{2}\right)$ & $\begin{array}{l}\mathrm{f}_{\mathrm{cm}, 28} \\
(\mathrm{MPa})\end{array}$ & $\begin{array}{l}\mathrm{w}(\mathrm{i}) \\
(\mathrm{mm})\end{array}$ \\
\hline $\mathrm{X} 1 / \mathrm{X} 4$ & 6096 & 203.2 & 304.8 & 400 & 400 & 600 & 685 & 25.34 & 14.22 \\
$\mathrm{X}$ /X5 & 6096 & 203.2 & 304.8 & 400 & 200 & 600 & 685 & 25.34 & 14.48 & 32.26 \\
X3/X6 & 6096 & 203.2 & 304.8 & 400 & 0 & 600 & 685 & 25.34 & 15.75 & 37.85 \\
Y1/Y4 & 6340 & 152.4 & 203.2 & 516 & 516 & 1000 & 1000 & 27.51 & 22.61 & 45.97 \\
Y2/Y5 & 6340 & 152.4 & 203.2 & 516 & 258 & 1000 & 1000 & 27.51 & 23.62 & 49.78 \\
Y3/Y6 & 6340 & 152.4 & 203.2 & 516 & 0 & 1000 & 1000 & 27.51 & 25.40 & 59.94 \\
\hline
\end{tabular}


Table 10. FE analyses vs. measured values, [22]

\begin{tabular}{lllll}
\hline Exp. & $\begin{array}{l}\mathrm{w}(\mathrm{i}) \\
(\mathrm{mm})\end{array}$ & $\begin{array}{l}\text { FE/Exp. } \\
(\%)\end{array}$ & $\begin{array}{l}\mathrm{w}(\mathrm{t}) \\
(\mathrm{mm})\end{array}$ & $\begin{array}{l}\text { FE/Exp. } \\
(\%)\end{array}$ \\
\hline $\mathrm{X} 1 / \mathrm{X} 4$ & 16.2 & 113.9 & 29.5 & 101.9 \\
$\mathrm{X} 2 / \mathrm{X} 5$ & 16.3 & 112.6 & 32 & 99.2 \\
$\mathrm{X} 3 / \mathrm{X} 6$ & 16.5 & 104.8 & 36.7 & 97.0 \\
$\mathrm{Y} 1 / \mathrm{Y} 4$ & 24.6 & 108.9 & 42.3 & 92.0 \\
$\mathrm{Y} 2 / \mathrm{Y} 5$ & 25 & 105.8 & 46.5 & 93.4 \\
$\mathrm{Y} 3 / \mathrm{Y} 6$ & 25.5 & 100.4 & 54.5 & 90.9 \\
\hline & $\mu=$ & 107.7 & $\mu=$ & 95.7 \\
& $\sigma=$ & 5.1 & $\sigma=$ & 4.3 \\
\hline
\end{tabular}

Again very good agreement with measured values is achieved, all results are within $\pm 15 \%$ of the experimental values.

The same FE model behavior and trends outlined in section 3.2 are also present here i.e. overestimation of initial deflection (along with increasing accuracy with decreasing compressive reinforcement) and underestimation of long-term deflection development (again the uncontrolled relative humidity to an extent diminishes the value of this conclusion).

\section{CONCLUSIONS}

This work presented a calibration and validation process of a numerical model for modeling the longterm behavior or reinforced concrete beams. From the previous sections the following conclusions are drawn:

- DIANA is a versatile software with a wide range of possible material and element models and analysis procedures. It is well suited for modeling the long-term behavior of reinforced concrete beams.

- The initial FE model presented in DIANA User's Manual ConcMas [3] as a benchmark test for long-term behavior of RC beams, can be improved upon through a parametric study. Within the boundaries of parametric study it was shown that a Multi-Directional Fixed Crack model with constant stress cut-off, nonlinear tension softening according to Hordijk et al. [15] and constant shear retention is best suited for modeling the cracking behavior of concrete in this application. For modeling creep and shrinkage the CEB-FIP Model Code 1990 was shown to be the most precise model in the range of linear creep.

- The model was successfully validated on 14 simply supported and 6 continuous beams with very good agreement $( \pm 15 \%)$. The model systematically overestimates the initial deflection. Accuracy is better when there is no compressive reinforcement. The CEB-FIP creep and shrinkage model tends to undersestimate the long-term deflection development.

\section{ACKNOWLEDGMENTS}

The work reported in this study is a part of the investigation within the Research Project TR36017: 'Utilization of by-products and recycled waste materials in concrete composites in the scope of sustainable construction development in Serbia: investigation and environmental assessment of possible applications', supported by the Ministry for Education, Science and Technology, Republic of Serbia This support is gratefully acknowledged.

\section{LITERATURE}

[1] Maekawa K. ed., Vecchio F. ed., Foster S.ed., Practitioner's guide to finite element modeling of reinforced concrete structures Lausanne: International Federation for Structural Concrete, 2008.

[2] Jonna M. ed., Schreppers G.J. ed., DIANA Finite Element Analysis User's Manual Getting Started Release 9.4.4. Delft: TNO DIANA BV, 2012.

[3] Jonna M. ed., DIANA Finite Element Analysis User's Manual Concrete and Masonry Analysis Release 9.4.4. Delft: TNO DIANA BV, 2011.

[4] Jaccoud J. P., Favre R., Flèche des structures en béton armé, Annales d l'institut technique de bâtiment et des Travaux Publics, 406 (1982).

[5] Espion, B. Benchmark examples for creep and shrinkage analysis computer programs, Proceedings of the 5th Int. RILEM Symposium on Creep and Shrinkage of Concrete (Barcelona, 1993), 877-888.

[6] Vonk, R. A., Rots, J. G., Kanstad, T., Ulm, F. J., and Navratil, J. Examples of evaluation of computer codes for creep and shrinkage analysis of concrete structures computer programs, Proceedings of the 5th Int. RILEM Symposium on Creep and Shrinkage of Concrete (Barcelona, 1993), 889-924.

[7] Borst, de, R., and Nauta, P. Non-orthogonal cracks in a smeared finite element model. Engineering Computations 2 (1985), 35-46.

[8] Riggs, H. R., and Powell, G. H. Rough crack model for analysis of concrete. J. Eng. Mech. Div., ASCE 112, 5 (1986), 448-464.

[9] Rots, J. G. Computational Modeling of Concrete Fracture. PhD thesis, Delft University of Technology, 1988.

[10] Reinhardt, H. W. Fracture mechanics of an elastic softening material like concrete. Heron 29, 2 (1984).

[11]CEB-FIP. CEB-FIP Model Code 1990. Comité Euro-International du Béton, 1993. 
[12] Jonna M. ed., Kikstra W. P. ed., DIANA Finite Element Analysis User's Manual Material Library Release 9.4.4. Delft: TNO DIANA BV, 2012.

[13] Jonna M. ed., Kikstra W. P. ed., DIANA Finite Element Analysis User's Manual Analysis Procedures Release 9.4.4. Delft: TNO DIANA BV, 2012.

[14] Pecic, N. Improved method for deflection control of reinforced concrete structures. PhD thesis, Faculty of Civil Engineering University of Belgrade, 2012.

[15]Hordijk, D. A., Cornelissen, H. A. W. and Reinhardt, H. W. Experimental determination of crack softening characteristics of normal weight and lightweight concrete. Heron 31, 2 (1986).

[16] ACI. Prediction of Creep, Shrinkage, and Temperature Effects in Concrete Structures. Tech. Rep. ACI 209R-92, American Concrete Institute, 1997.

[17] NEN. TGB 1990 Regulations for concrete Stuctural requirements and calculation methods. Tech. Rep. NEN 6720, Nederlands Normalisatieinstituut, 1995.
[18] Espion, B. Long term sustained loading tests on reinforced concrete beams - A selected data base, Université Libre de Bruxelles Service Génie Civil, Bulletin 88-1, 1988.

[19] Washa G. W., Fluck P. G., Effect of compressive reinforcement on the plastic flow of reinforced concrete beams, Proc. ACI, 49, 1952, 89-108

[20] Glanville W. H., Thomas F.G., Studies in reinforced concrete: IV, Further studies on the creep or flow of concrete under load, Building research technical paper, 21, Department of scientific and industrial research (London, H.M.S.O.), 1939, 43 pp.

[21] Hognestad E. (principal consultant at Portland Cement Association), private correspondence with B. Espion, August 1987.

[22] Washa G.W., Fluck P.G., Plastic flow (creep) of reinforced concrete continuous beams, Proc. ACI, $52,1956,549-561$

\section{REZIME}

\section{KALIBRACIJA I VERIFIKACIJA MODELA KONAČNIH ELEMENATA ZA DUGOTRAJNO PONAŠANJE AB GREDA}

U ovom radu je predstavljeno istraživanje sprovedeno u svrhu pronalaženja optimalnog modela konačnih elemenata za predviđanje ponašanja armirano-betonskih greda pod dugotrajnim opterećenjem. $U$ istraživanju je korišćen višenamenski komercijalni softver DIANA. Za kalibraciju modela je odabran benčmark test $u$ vidu proste grede opteré́ene savijanjem u četiri tačke. Kao rezultat kalibracije, odabrani model se sastojao od linijskih konačnih elemenata sa tri čvora. Odabran je model fiksne prsline u više pravaca. Sadejstvo zategnutog betona između prslina opisano je nelinearnom funkcijom. Odabrana je konstantna rezidualna nosivost pri smicanju. Skupljanje i tečenje je modelirano prema CEB-FIP Model Code 1990. Model je dodatno verifikovan na 14 prostih greda i 6 kontinualnih greda sa dva polja. Rezultati su pokazali dobro slaganje sa eksperimentalnim vrednostima $( \pm 15 \%)$.

Ključne reči: tečenje, skupljanje, armirani beton, grede, konačni elementi 